\title{
HUBUNGAN ASUPAN GIZI DAN STATUS GIZI IBU HAMIL TRIMESTER III DENGAN BERAT BADAN LAHIR BAYI DI WILAYAH KERJA PUSKESMAS SURUH KABUPATEN SEMARANG
}

\author{
Siva Candra Rukmana, Martha Irene Kartasurya ${ }^{*}$ \\ Program Studi Ilmu Gizi Fakultas Kedokteran Universitas Diponegoro \\ J1.Dr.Sutomo No.18, Semarang, Telp (024) 8453708, Email : gizifk@ undip.ac.id
}

\begin{abstract}
Background: Low birth weight $(L B W)$ is one of the major nutrition problems that have an impact on neonatal mortality. This issue is affected by many factors, including maternal intake and nutritional status. The LBW prevalence in Puskesmas Suruh, Semarang Region was 4,2\%, higher than Central Java Province prevalence $(3,7 \%)$. The goal of the study is to prove the association between maternal intake and pregnant women nutritional status with the birthweight in Puskesmas Suruh.

Method: This study was an observational analytic research with a longitudinal approach. The population was all of pregnant women in the third trimester in Puskesmas Suruh. Subjects (35 pregnant women) were selected by consecutive sampling method. The dependent variable was birthweight. The independent variables were maternal intake (energy, protein, iron, folate) and nutritional status (Mid Upper Arm Circumference and hemoglobin levels). Data analysis was done by Correlation tests (Pearson and Spearman) and multiple linear regression method.

Results: The average age of subjects were $26 \pm 5.92$ years. All subjects were deficient in energy and folate intake, based on Indonesian RDA, while $91.4 \%$ and $25.7 \%$ of the subjects were deficient in protein and iron intake consecutively, based on Indonesian RDA. It was found that the average of hemoglobin levels was $10.9 \pm 0.62 \mathrm{~g} / \mathrm{dl}$ and MUAC was $25.4 \pm 1.78 \mathrm{~cm}$. The percentage of anemia was $57.1 \%$ and chronic energy deficiency based on MUAC was

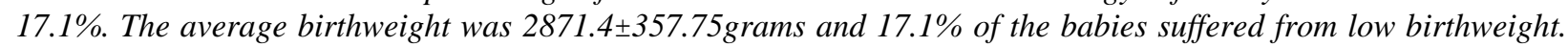
Factors associated to birthweight were energy sufficiency level $(r=0.568 p=0.0001)$, protein sufficiency level $(r=$ $0.541 p=0.001)$, iron intake ( $r=0.433 p=0.005)$, folate intake $(r=0.301 p=0.039)$, hemoglobin levels and MUAC. The linear regression showed that protein sufficiency level and iron intake of pregnant women were determinant factors of birthweight.
\end{abstract}

Conclusion: Pregnant women protein sufficiency level and iron intake in the third trimester associated to birthweight.

Keyword: Birthweight; energy sufficiency level; protein sufficiency level; hemoglobin levels of pregnant women

\section{ABSTRAK}

Latar belakang: Berat Badan Lahir Rendah (BBLR) merupakan salah satu masalah gizi yang berdampak pada kematian bayi. Faktor yang mempengaruhi berat lahir bayi meliputi asupan gizi ibu dan status gizi ibu. Prevalensi BBLR Puskesmas Suruh Kabupaten Semarang sebesar 4,2\%, lebih tinggi dari prevalensi Provinsi Jawa Tengah (3,7\%). Tujuan penelitian ini adalah membuktikan hubungan asupan gizi dan status gizi ibu hamil trimester III dengan berat badan lahir bayi di wilayah kerja Puskesmas Suruh.

Metode: Jenis penelitian ini adalah analitik observasional dengan pendekatan longitudinal. Populasi penelitian adalah semua ibu hamil trimester III di Puskesmas Suruh. Pemilihan subjek (35 ibu hamil) dilakukan secara consecutive sampling. Variabel terikat adalah berat bayi lahir. Variabel bebas meliputi asupan gizi ibu (tingkat kecukupan energi, tingkat kecukupan protein, asupan Fe, asupan folat) dan status gizi ibu (lingkar lengan atas dan kadar hemoglobin). Data dianalisis menggunakan uji korelasi Pearson dan Spearman kemudian dilanjutkan dengan regresi linier ganda.

Hasil penelitian: Rerata umur ibu adalah 26+5,92 tahun. Dibandingkan dengan AKG, asupan energi, protein, Fe dan folat berada dalam kategori kurang sebesar 100\%, 91,4\%, 25,7\% dan 100\%. Rerata kadar hemoglobin $(10,9 \pm 0,62) \mathrm{g} / \mathrm{dl}$ dan lingkar lengan atas ibu $(25,4 \pm 1,78) \mathrm{cm}$. Persentase anemia pada ibu hamil $57,1 \%$ dan jumlah ibu hamil dengan KEK 17,1\%. Rerata berat lahir bayi sebesar 2871,4+357,75 gram dan 17,1\% menderita berat badan lahir rendah. Ada hubungan tingkat kecukupan energi ( $r=0,568 p=0,0001)$, tingkat kecukupan protein $(r=0,541 p=0,001)$, asupan Fe/hari $(r=0,433 p=0,005)$, asupan folat/hari $(r=0,301 p=0,039)$, lingkar lengan atas ibu $(r=0,381 p=0,012)$ dan kadar hemoglobin ibu $(r=0,431 p=0,005)$ dengan berat bayi lahir. Secara multivariat, tingkat kecukupan protein dan asupan Fe/hari pada ibu hamil merupakan faktor determinan berat badan lahir bayi. Simpulan: Tingkat kecukupan protein dan asupan Fe/hari ibu hamil trimester III berhubungan dengan berat badan lahir bayi.

Kata kunci: Berat badan lahir; Tingkat kecukupan energi; Tingkat kecukupan protein; Kadar hemoglobin ibu hamil 


\section{PENDAHULUAN}

Masalah gizi masih merupakan masalah kesehatan masyarakat yang utama di negara berkembang termasuk Indonesia. Masalah gizi menjadi penyebab kematian ibu dan anak secara tidak langsung yang sebenarnya masih dapat dicegah. Rendahnya asupan gizi dan status gizi ibu hamil selama kehamilan dapat mengakibatkan berbagai dampak tidak baik bagi ibu dan bayi. Salah satunya adalah bayi lahir dengan berat badan lahir rendah (BBLR), yaitu berat badan lahir di bawah 2500 gram. Bayi yang terlahir BBLR memiliki peluang meninggal 35 kali lebih tinggi dibandingkan dengan berat badan lahir di atas 2500 gram. ${ }^{1}$ Penurunan kejadian BBLR dapat dicapai melalui pengawasan pada ibu hamil dengan menemukan dan memperbaiki faktor yang mempengaruhi pertumbuhan dan perkembangan janin dan neonatus. $^{2}$

Angka kejadian BBLR di Indonesia tahun 2010 sebesar $11,1 \%$ dari $84,8 \%$ bayi yang ditimbang. ${ }^{3}$ Dinas Kesehatan Provinsi Jawa Tengah menunjukkan persentase BBLR tahun 2011 sebesar 3,73\%, meningkat dibandingkan tahun 2010 sebesar 2,69\%. Data pemantauan berat badan lahir di Puskesmas Suruh, Kecamatan Suruh Kabupaten Semarang menunjukkan prevalensi BBLR sebesar 2\% di tahun 2011, sedangkan pemantauan terakhir tahun 2012 meningkat menjadi $4,2 \%$.

Kejadian BBLR erat kaitannya dengan status gizi. Status gizi ibu hamil baik sebelum maupun selama hamil, dapat menggambarkan ketersediaan zat gizi dalam tubuh ibu untuk mendukung pertumbuhan janin. Prediktor status gizi ibu selama hamil dapat dilakukan dengan pengukuran lingkar lengan atas (LLA) dan pemeriksaan hemoglobin. ${ }^{4}$

Pengukuran LLA pada ibu hamil berkaitan dengan kekurangan energi kronik (KEK). KEK merupakan masalah yang sering terjadi pada ibu hamil. LLA < 23,5 cm harus mendapatkan penanganan agar tidak terjadi komplikasi pada janin. Gizi kurang pada ibu hamil dapat menyebabkan risiko dan komplikasi pada ibu, seperti anemia, perdarahan dan berat badan ibu tidak bertambah secara normal serta terkena penyakit infeksi. Ibu yang mengalami KEK akan lebih berisiko melahirkan BBLR. ${ }^{5}$

Masalah lain yang sering terjadi selama kehamilan adalah penurunan kadar hemoglobin akibat peningkatan volume plasma yang lebih banyak daripada volume sel darah merah. Penurunan ini terjadi pada usia kehamilan 8 sampai 32 minggu. Anemia dapat menyebabkan pengangkutan oksigen menjadi terganggu sehingga nutrisi ke janin berkurang. ${ }^{6}$

Anemia pada ibu hamil dapat terjadi karena kekurangan beberapa zat gizi mikro, salah satunya adalah besi (Fe). Terbukti bahwa penduduk Indonesia pada umumnya mengkonsumsi Fe yang berasal dari sumber nabati, yang mempunyai daya serap rendah dibanding sumber hewani. Kebutuhan janin akan $\mathrm{Fe}$ terakumulasi pada trimester terakhir sehingga diperlukan penambahan suplemen Fe. Keadaan kurang $\mathrm{Fe}$ dapat menimbulkan gangguan pada pertumbuhan janin, baik sel tubuh maupun sel otak. $^{7}$

Zat gizi mikro yang juga berperan dalam kehamilan adalah folat. Folat digunakan untuk pertumbuhan sel dan replikasi pada janin atau plasenta. Kekurangan folat terjadi karena konsumsi kurang atau kebutuhan metabolik yang meningkat. Kekurangan folat dalam waktu yang lama dapat memicu terjadinya anemia defisiensi folat, belum matangnya sel darah merah. Kekurangan folat selama kehamilan berhubungan dengan peningkatan risiko kelahiran prematur, berat lahir rendah dan terganggunya pertumbuhan janin. ${ }^{8}$

Berat lahir juga berhubungan dengan pemenuhan nutrisi selama kehamilan, salah satunya adalah kebutuhan zat gizi makro. Kebutuhan gizi meningkat seiring bertambahnya usia kehamilan, pertumbuhan dan perkembangan janin bersama dengan perubahan jaringan serta metabolisme tubuh ibu. Pertumbuhan dan perkembangan janin semakin cepat pada kehamilan trimester ketiga sehingga diperlukan asupan energi dan protein yang cukup. Tingkat kecukupan gizi selama hamil berpengaruh terhadap berat badan lahir. ${ }^{9}$

Penelitian ini bertujuan untuk membuktikan hubungan asupan gizi dan status gizi ibu hamil trimester III dengan berat lahir bayi di wilayah kerja Puskesmas Suruh.

\section{METODE PENELITIAN}

Penelitian ini dilakukan di wilayah kerja Puskesmas Suruh. Penelitian ini merupakan penelitian observasional pada lingkup gizi masyarakat dengan studi longitudinal dan pendekatan prospektif. Data diambil pada bulan Juni - Agustus 2013.

Populasi dari penelitian ini adalah semua ibu hamil trimester III yang berdomisili di wilayah kerja tersebut. Subjek (35 ibu hamil) dipilih secara consecutive sampling dan telah memenuhi kriteria 
inklusi dan eksklusi. Kriteria inklusi pada penelitian ini adalah ibu hamil trimester III yang bersedia menjadi responden penelitian, tinggal menetap di wilayah tersebut, usia kehamilan memasuki trimester III dan bersedia melakukan pemeriksaan kadar hemoglobin. Kriteria eksklusi yaitu ibu yang sedang dirawat di rumah sakit karena penyakit tertentu, ibu meninggal, bayi prematur dan mengalami abortus dalam kehamilannya.

Variabel terikat dalam penelitian ini yaitu berat badan lahir bayi. Berat badan lahir diukur dalam 30 menit setelah persalinan menggunakan timbangan bayi (baby scale) dengan ketelitian 100 gram. Variabel bebas meliputi asupan gizi (tingkat kecukupan energi, tingkat kecukupan protein, asupan Fe/hari, asupan folat/hari) dan status gizi ibu hamil trimester III (lingkar lengan atas ibu, kadar hemoglobin ibu).

Data asupan energi, protein, fe dan folat diperoleh menggunakan form food recall $2 \times 24$ jam sebanyak 3 kali yaitu 2 kali pada bulan ke-1, 2 kali pada bulan ke-2 dan 2 kali di bulan ke-3, kemudian dihitung dengan software Nutrisurvey. Kebutuhan energi dihitung dengan membedakan usia ibu, untuk usia $\geq 19$ tahun menggunakan rumus TEE $=$ $354-(6,91 \times$ usia [th] $)+$ PA x [(9,36 x BB [kg] $)]$ $+(726 \times$ TB $[\mathrm{m}])$. Untuk usia 14-18 tahun menggunakan rumus TEE $=135,3-(30,8 \times$ usia $[\mathrm{th}])+\mathrm{PA} \times[(10,0 \times \mathrm{BB}[\mathrm{kg}])+(934 \mathrm{x} \mathrm{TB}[\mathrm{m}])]+$ 25. Kebutuhan energi ibu hamil trimester III = TEE + 452 kkal. $^{10}$

Data antropometri yang diukur meliputi : data berat badan (BB) ibu yaitu berat badan sebelum hamil yang diperoleh dari data sekunder, dinyatakan dalam satuan $\mathrm{kg}$. Tinggi badan (TB) yaitu tinggi badan pada saat pengambilan data, diukur dengan menggunakan microtoise dengan ketelitian $0,1 \mathrm{~cm}$. Data berat badan dan tinggi badan ibu hamil digunakan dalam perhitungan kebutuhan energi.

Lingkar lengan atas diukur menggunakan pita LLA dengan ketelitian $0,1 \mathrm{~cm}$ tepat pada titik tengah lengan atas antara acromion process dan olecranon process, dinyatakan dalam satuan $\mathrm{cm}$. Kadar hemoglobin diukur menggunakan Hemocue oleh petugas laboratorium puskesmas, dinyatakan dalam satuan $\mathrm{g} / \mathrm{dl}$.

Analisis univariat dilakukan untuk mendeskripsikan setiap variabel penelitian. Analisis bivariat digunakan untuk mengetahui ada atau tidaknya hubungan antara varibel yaitu tingkat kecukupan energi, tingkat kecukupan protein, asupan $\mathrm{Fe}$, asupan folat, lingkar lengan atas ibu, kadar hemoglobin ibu dengan berat badan lahir bayi. Uji normalitas data menggunakan ShapiroWilk. Data berdistribusi normal yaitu tingkat kecukupan energi, tingkat kecukupan protein, asupan Fe, asupan folat, lingkar lengan atas ibu, kadar hemoglobin ibu dan usia ibu digunakan uji korelasi Pearson, sedangkan data tidak berdistribusi normal meliputi variabel pendidikan dan pekerjaan ibu digunakan uji korelasi Spearman. Analisis multivariat yang digunakan adalah regresi linier ganda.

\section{HASIL PENELITIAN \\ Karakteristik}

Responden dalam penelitian ini berjumlah 35 ibu hamil yang memasuki usia kehamilan di atas 28 bulan yaitu trimester III. Karakteristik ibu berdasarkan usia terdapat pada Tabel 1 .

Tabel 1. Distribusi Frekuensi Berdasarkan Usia Ibu

\begin{tabular}{lllll}
\hline Variabel & n & \% & Mean (th) & SD (th) \\
\hline Usia Ibu & & & & \\
$<20$ tahun & 9 & 25,7 & 26,0 & 5,92 \\
$20-35$ tahun & 24 & 68,6 & & \\
$>35$ tahun & 2 & 5,7 & & \\
\hline
\end{tabular}

Tabel 1 menunjukkan bahwa di wilayah Puskesmas Suruh masih terdapat kehamilan pada usia $<20$ tahun sebesar $25,7 \%$.

Tabel 2. Distribusi Frekuensi Pendidikan dan Pekerjaan Ibu

\begin{tabular}{clll}
\hline No & Variabel & n & \% \\
\hline 1 & Pendidikan & & \\
& Tidak tamat SD & 2 & 5,7 \\
& SD/MI & 10 & 28,6 \\
\hline
\end{tabular}




\begin{tabular}{llll}
\hline & SMP/MTs & 12 & 34,3 \\
& SMA/SMK/MA & 8 & 22,9 \\
& D3/PT & 3 & 8,6 \\
\hline 2 & Pekerjaan & & \\
& Ibu rumah tangga & 13 & 37,1 \\
PNS & 2 & 5,7 \\
& Swasta & 16 & 40,0 \\
Wiraswasta & 6 & 17,1 \\
\hline
\end{tabular}

Tabel 2 menunjukkan bahwa pendidikan ibu yang masih rendah yaitu SD dan SMP. Pekerjaan ibu mayoritas sebagai ibu rumah tangga dan swasta.

\section{Asupan Gizi Responden}

Faktor yang mempengaruhi kehamilan salah satunya asupan gizi ibu yang diperoleh dari konsumsi makanan. Asupan disesuaikan dengan kebutuhan gizi individu. Distribusi frekuensi energi, protein, Fe dan folat dipaparkan pada Tabel 3.

Tabel 3. Distribusi Frekuensi Berdasarkan Asupan Energi, Protein, Fe dan Folat

\begin{tabular}{llllc}
\hline Variabel & n & \% & Mean & SD \\
\hline Tingkat Kecukupan & & & & \\
Energi & 35 & 100 & & 5,38 \\
Kurang $(<100 \% \mathrm{AKG})$ & 0 & 0 & 83,8 & \\
$\begin{array}{l}\text { Baik }(\geq 100 \% \mathrm{AKG}) \\
\text { Tingkat Kecukupan }\end{array}$ & 32 & 91,4 & & 2,33 \\
$\begin{array}{l}\text { Protein } \\
\text { Kurang }(<100 \% \mathrm{AKG})\end{array}$ & 3 & 8,6 & 62,7 & \\
$\begin{array}{l}\text { Baik }(\geq 100 \% \mathrm{AKG}) \\
\text { Asupan Fe/hari }\end{array}$ & 9 & 25,7 & & 11,43 \\
$\begin{array}{l}\text { Kurang }(<39 \mathrm{mg}) \\
\text { Baik }(\geq 39 \mathrm{mg})\end{array}$ & 26 & 74,3 & 49,7 & \\
$\begin{array}{l}\text { Asupan Folat/hari } \\
\text { Kurang }(<600 \mu \mathrm{g})\end{array}$ & 35 & 100 & & 40,96 \\
Baik $(\geq 600 \mu \mathrm{g})$ & 0 & 0 & 416,3 & \\
\hline
\end{tabular}

Tabel 3 menunjukkan bahwa asupan energi sehari semua ibu hamil kurang dari kebutuhan mereka. Hanya $8,6 \%$ ibu hamil yang dapat memenuhi kebutuhan protein perharinya. Sebagian besar ibu $(74,3 \%)$ sudah memenuhi kebutuhan $\mathrm{Fe}$ perhari, apabila suplemen $\mathrm{Fe}$ dimasukkan dalam perhitungan asupan perhari. Tidak ada satupun ibu yang memiliki asupan folat cukup, meskipun asupan folat dan suplemen sudah diperhitungkan.

\section{Status Gizi Responden}

Status gizi ibu hamil dapat diskrining dengan pengukuran lingkar lengan atas dan pemeriksaan kadar hemoglobin. Status gizi selama hamil terpapar pada Tabel 4.

Tabel 4. Distribusi Frekuensi Menurut Lingkar Lengan Atas dan Kadar Hemoglobin

\begin{tabular}{clllcc}
\hline No & Kategori status gizi & n & \% & Mean & SD \\
\hline 1 & Lingkar Lengan Atas & & & & \\
& KEK $<23,5 \mathrm{~cm}$ & 6 & 17,1 & 25,4 & 1,78 \\
& Tidak KEK $\geq 23,5 \mathrm{~cm}$ & 29 & 82,9 & & \\
\hline 2 & Kadar hemoglobin & & & & \\
& Anemia $<11 \mathrm{~g} / \mathrm{dl}$ & 20 & 57,1 & 10,9 & 0,62 \\
& Tidak Anemia $\geq 11 \mathrm{~g} / \mathrm{dl}$ & 15 & 42,9 & & \\
\hline
\end{tabular}


Tabel 4 menunjukkan bahwa dari 35 subjek penelitian yang menderita kurang energi kronis sebesar $(17,1 \%)$. Selain itu, setelah dilakukan pemeriksaan kadar hemoglobin ditemukan ibu hamil dengan anemia sebesar $57,1 \%$.

\section{Berat Badan Lahir Bayi}

Faktor ibu hamil merupakan faktor yang dapat mempengaruhi janin, salah satunya berat lahir. Berat badan lahir bayi tercantum pada Tabel 5 .

Tabel 5. Distribusi Frekuensi menurut Berat Badan Lahir Bayi

\begin{tabular}{lllcl}
\hline Berat bayi lahir & n & \% & Mean $(\mathbf{g})$ & SD (g) \\
\hline BBLR $<2500 \mathrm{~g}$ & 6 & 17,1 & \multirow{2}{*}{2871,4} & \multirow{2}{*}{357,75} \\
BBLN $\geq 2500 \mathrm{~g}$ & 29 & 82,9 & & \\
\hline Jumlah & 35 & 100 & & \\
\hline
\end{tabular}

Tabel 5 menunjukkan bahwa dari 35 ibu hamil, 6 bayi $(17,1 \%)$ dilahirkan dengan berat badan lahir rendah $(<2500$ gram $)$.

Hubungan Asupan Gizi dan Status Gizi Ibu Hamil Trimester III dengan Berat Badan Lahir Bayi
Analisis hubungan antara variabel asupan gizi (tingkat kecukupan energi, tingkat kecukupan protein, asupan Fe, asupan folat), status gizi (lingkar lengan atas dan kadar hemoglobin) dan variabel karakteristik ibu (usia, pendidikan, pekerjaan) dengan berat badan lahir bayi dapat dilihat pada Tabel 6 .

Tabel 6. Hubungan Antara Beberapa Variabel dengan Berat Badan Lahir Bayi

\begin{tabular}{cclcc}
\hline No & Variabel & & $\mathbf{r}$ & $\mathbf{p}$ \\
\hline 1 & Asupan gizi & Tingkat kecukupan energi & 0,568 & $0,0001^{*}$ \\
& & Tingkat kecukupan protein & 0,541 & $0,001^{*}$ \\
& & Asupan Fe & 0,433 & $0,005^{*}$ \\
& & Asupan Folat & 0,301 & $0,039^{*}$ \\
\hline 2 & \multirow{2}{*}{ Status gizi } & Lingkar lengan atas & 0,381 & $0,012^{*}$ \\
& & Kadar hemoglobin & 0,431 & $0,005^{*}$ \\
\hline 3 & Karakeristik & Usia ibu & 0,108 & $0,536^{*}$ \\
& ibu & Pendidikan & 0,069 & $0,693^{* *}$ \\
& & Pekerjaan & $-0,003$ & $0,988^{* *}$ \\
\hline
\end{tabular}

*Uji Korelasi Pearson

** Uji Korelasi Spearman

Asupan gizi ibu hamil di wilayah Puskesmas Suruh yang meliputi energi, protein, $\mathrm{Fe}$, folat berhubungan dengan berat bayi yang dilahirkan. Hal ini berarti semakin rendah asupan gizi ibu hamil akan berdampak pada rendahnya berat lahir bayi.

Tabel 6 juga memaparkan bahwa status gizi ibu hamil (lingkar lengan atas dan kadar hemoglobin) berhubungan dengan berat badan lahir. Kadar hemoglobin $<11 \mathrm{~g} / \mathrm{dl}$ dan KEK pada ibu hamil berkorelasi positif dengan rendahnya berat bayi yang dilahirkan. Selain itu, tidak ada hubungan karakteristik ibu (usia, pendidikan dan pekerjaan) dengan berat badan lahir bayi.

Analisis multivariat digunakan sebagai tindak lanjut dari analisis bivariat dengan mengikutsertakan variabel yang bermakna secara statistik $(\mathrm{p}<0,05)$ dan variabel yang memiliki nilai $\mathrm{p}<0,25$, yaitu tingkat kecukupan energi, tingkat kecukupan protein, asupan $\mathrm{Fe}$, asupan folat, lingkar lengan atas, kadar hemoglobin. Analisis yang digunakan adalah regresi linier ganda. Hasil analisis multivariat dapat dilihat pada Tabel 7.

Tabel 7. Hubungan Beberapa Faktor dengan Berat Badan Lahir Bayi

\begin{tabular}{|c|c|c|c|c|c|}
\hline Variabel & & $\mathbf{B}$ & $\boldsymbol{\beta}$ & $\mathbf{t}$ & $\mathbf{p}$ \\
\hline (Constant) & & 726,066 & 391,874 & 1,853 & 0,073 \\
\hline Tingkat & kecukupan & 16,871 & 3,856 & 4,376 & 0,0001 \\
\hline
\end{tabular}




\begin{tabular}{|c|c|c|c|c|}
\hline $\begin{array}{l}\text { protein } \\
\text { Asupan } \mathrm{Fe}\end{array}$ & 13,940 & 3,944 & 3,534 & 0,001 \\
\hline
\end{tabular}

Adjusted R Square $=0,460$

Tabel 7 menunjukkan persamaan berat badan lahir $=726,066+16,871$ (tingkat kecukupan protein) $+13,940$ (asupan Fe). Setiap kenaikan tingkat kecukupan protein $1 \%$ maka berat badan lahir bayi akan naik sebesar 16,871 gram. Kenaikan asupan Fe $1 \mathrm{mg}$, berat badan lahir bayi akan meningkat 13,940 gram. Jadi variabel tingkat kecukupan protein dan asupan $\mathrm{Fe}$ berhubungan dengan berat badan lahir bayi sebesar $46,0 \%$.

\section{PEMBAHASAN}

\section{Karakteristik Responden}

Usia yang paling baik untuk kehamilan adalah 20-35 tahun, diharapkan gizi ibu hamil akan lebih baik. Variabel usia ibu tidak berhubungan dengan berat badan lahir bayi. Namun penelitian ini menunjukkan bahwa salah satu ibu yang berusia di atas 35 tahun ternyata melahirkan bayi dengan berat lahir rendah. Usia ini memiliki fungsi organ yang mulai melemah dan diharuskan untuk bekerja, sehingga memerlukan tambahan energi yang cukup untuk mendukung kehamilan yang sedang berlangsung. ${ }^{11}$ Selain itu, ditemukan juga 2 ibu hamil yang berusia kurang dari 20 tahun yang melahirkan bayi lahir rendah. Karena usia kurang dari 20 tahun masih merupakan masa pertumbuhan dan perkembangan, juga harus berbagi dengan janin yang sedang dikandung sehingga berpengaruh pada pemenuhan kebutuhan gizi selama kehamilan. Dari segi kejiwaan, remaja belum siap dalam menghadapi emosional yang menyebabkan stress psikologis yang dapat mengganggu perkembangan janin. ${ }^{12}$

Pendidikan dan pekerjaan ibu hamil tidak berhubungan dengan berat lahir bayi. Namun responden di wilayah kerja Puskesmas paling mendominasi berpendidikan SD dan SMP. Tingkat pendidikan seseorang mempengaruhi tingkat pengetahuan. Semakin tinggi tingkat pendidikan ibu semakin tinggi pula tingkat pengetahuannya. Pengetahuan ibu hamil yang baik tentang faktor yang mempengaruhi pertumbuhan dan perkembangan janin diharapkan status gizi bayi baik pula. Selain itu, semakin tinggi tingkat pendidikan seseorang semakin tinggi pula peluang untuk mendapatkan pekerjaan yang lebih baik. Tingkat pendapatan keluarga mempengaruhi pemilihan bahan makanan yang akan dikonsumsi selama kehamilan yang berdampak pada status gizi ibu hamil. ${ }^{13}$

\section{Hubungan Asupan Gizi (Tingkat Kecukupan Energi, Tingkat Kecukupan Protein, Asupan Fe dan Asupan Folat) dengan Berat Badan Lahir Bayi}

Asupan gizi ibu hamil terbagi dalam zat gizi makro dan mikro, namun dalam penelitian ini hanya diteliti tentang asupan energi, protein, $\mathrm{Fe}$ dan folat. Tabel 3 menunjukkan bahwa asupan zat gizi ibu hamil di wilayah Puskesmas Suruh yang rendah, tidak ada satupun ibu memiliki asupan energi yang cukup. Kondisi asupan gizi yang demikian dapat mengganggu pertumbuhan dan perkembangan janin., ${ }^{6,14}$ Tabel 5 menunjukkan ditemukan bayi dengan berat badan lahir rendah sebesar 17,1\%. Angka ini lebih tinggi dibandingkan prevalensi BBLR di Jawa Tengah sebesar 9,9\%. ${ }^{3}$ Asupan gizi yang kurang dapat menjadi salah satu faktor terjadinya BBLR di wilayah ini. Hal ini menggambarkan bahwa ibu hamil yang memiliki asupan energi yang rendah juga melahirkan bayi dengan berat lahir rendah. Sesuai dengan penelitian di India, asupan energi pada wanita hamil dapat digunakan sebagai faktor prediktor terhadap berat lahir bayi. ${ }^{15}$ Terjadi peningkatan kejadian BBLR di wilayah Puskesmas Suruh dari tahun 2012 sebesar 4,2 menjadi 17,1\% pada tahun 2013. Kejadian ini dimungkinkan karena data pengukuran berat badan lahir bayi yang kurang valid atau bayi yang lahir belum tercatat semua di puskesmas.

Penelitian ini ditemukan bahwa konsumsi sumber protein sebagian besar dipenuhi dari protein nabati yaitu tahu dan tempe. Hanya beberapa yang mengkonsumsi protein hewani yaitu telur dan susu, tetapi terdapat 5 ibu yang mengkonsumsi susu khusus ibu hamil. Kondisi tersebut terlihat pada Tabel 3 bahwa hanya 5,7\% asupan protein ibu hamil dapat terpenuhi. Asupan protein yang demikian menjadi peluang kejadian BBLR di Puskesmas Suruh. Karena selama kehamilan protein diperlukan plasenta untuk membawa makanan ke janin, pembentuk hormon dan enzim ibu dan janin. Adanya kekurangan energi dan protein menyebabkan terbentuknya organ yang lebih kecil dengan jumlah sel yang cukup dan ukuran sel yang kecil sehingga ukuran plasenta menjadi kecil. Volume darah ibu menurun dan cardiac output tidak adekuat. Hal ini mengakibatkan menurunnya aliran darah ke plasenta diikuti transfer nutrisi berkurang sehingga 
pertumbuhan janin terganggu dan berdampak pada berat badan lahirnya. ${ }^{16}$ Terlihat pada Tabel 5 bahwa tingginya persentase BBLR $(17,1 \%)$ di wilayah Puskesmas ini. Penelitian ini serupa dengan penelitian lain yang mengatakan bahwa asupan protein pada trimester III yang rendah akan menyebabkan rendahnya berat lahir bayi. ${ }^{15}$

Kebutuhan akan $\mathrm{Fe}$ juga mengalami peningkatan untuk pembentukan plasenta dan sel darah merah. Pemenuhan kebutuhan diperoleh baik dari makanan maupun pemberian suplementasi. Kebutuhan $\mathrm{Fe}$ lebih tinggi daripada rata-rata asupan yang diserap tubuh. Penyerapan $\mathrm{Fe}$ tergantung pada sumber makanan yang dikonsumsi. Penelitian ini ditemukan bahwa 25,7\% ibu hamil memiliki asupan Fe kurang. Terlahir 5 bayi BBLR dari ibu hamil yang kurang asupan Fe. Masih ditemukan ibu hamil yang tidak rutin mengkonsumsi tablet $\mathrm{Fe}$, sering dikonsumsi bersamaan dengan minum teh dan susu. Teh mengandung tannin dan susu mengandung kalsium, dapat menghambat penyerapan $\mathrm{Fe}^{17}$ Karena kekurangan $\mathrm{Fe}$ dapat menimbulkan gangguan pada pertumbuhan janin baik pada sel tubuh maupun sel otak. Fe dikaitkan dengan anemia gizi besi, menjadi salah satu kontribusi terjadinya anemia ibu hamil $(57,1 \%)$ pada Tabel 4. Kondisi ini dapat mengakibatkan kematian janin dalam kandungan, abortus, cacat bawaan, berat lahir rendah dan menyebabkan bayi lahir dengan anemia. ${ }^{15,18-19}$

Penelitian ini diketahui bahwa semua ibu hamil memiliki asupan folat perhari yang kurang. Asupan folat yang kurang pada Tabel 4 dengan kondisi anemia ibu hamil $(57,1 \%)$ dapat menjadi salah satu penyebab berat badan lahir bayi rendah $(17,1 \%)$. Konsumsi makanan saja tidak cukup untuk memenuhi kebutuhan folat. Ditemukan ibu hamil tidak rutin dalam mengkonsumsi suplementasi folat. Folat selama kehamilan mempengaruhi berat plasenta yang merupakan faktor penentu dari berat janin. Kekurangan folat selama kehamilan dapat menjadi faktor risiko malformasi janin dan berbagai penyakit yang berhubungan dengan plasenta. Penelitian ini sesuai dengan penelitian cross sectional bahwa asupan folat ibu hamil mempengaruhi antropometri bayi yaitu berat lahir dan panjang lahir. ${ }^{16,19-20}$

Hubungan Status Gizi (LLA dan Kadar Hb) Ibu Hamil Trimester III dengan Berat Badan Lahir Bayi

Pengukuran LLA merupakan salah satu cara deteksi dini untuk mengetahui risiko Kurang Energi Kronik (KEK), tidak terpenuhinya kebutuhan energi dan protein dalam jangka waktu yang panjang. Tabel 4 menunjukkan bahwa $17,1 \%$ ibu hamil dengan LLA $<23,5 \mathrm{~cm}$ (KEK), terlihat pada asupan energi dan proteinnya yang kurang. Angka KEK ini lebih tinggi dibandingkan prevalensi KEK di Jawa Tengah sebesar 14,7\%. ${ }^{3}$ Selain itu, ditemukan pula 2 bayi dengan BBLR dilahirkan dari ibu hamil KEK. Hal ini sesuai dengan pernyataan bahwa asupan gizi ibu hamil yang kurang dan tidak mencukupi untuk menyediakan kebutuhan fisiologis kehamilan yakni perubahan hormon, meningkatnya volume darah untuk pertumbuhan janin sehingga suplai zat gizi pada janinpun berkurang. Akibatnya pertumbuhan dan perkembangan janin terhambat dan lahir dengan berat yang rendah. ${ }^{21-22}$

Kadar hemoglobin kurang dari $11 \mathrm{~g} / \mathrm{dl}$ dikatakan sebagai keadaan anemia. Anemia dalam kehamilan terjadi pada kondisi yang disebabkan oleh penambahan volume plasma yang relatif lebih besar daripada volume sel darah merah. Tabel 4 menunjukkan bahwa tingginya anemia pada ibu hamil di Puskesmas Suruh sebesar $57,1 \%$. Penelitian ini ditemukan bahwa semua bayi yang $\operatorname{BBLR}(17,1 \%)$ dilahirkan oleh ibu hamil dengan anemia. Selain kondisi fisiologis ibu, kondisi asupan gizi yang kurang pada Tabel 3 dapat menjadi faktor pemicu terjadinya anemia. Anemia ibu hamil dapat mengakibatkan berkurangnya suplai oksigen ke jaringan dan akan mengganggu pertumbuhan janin, sehingga akan memperkuat risiko terjadinya persalinan prematur dan berat badan bayi lahir rendah. ${ }^{23}$ Selain itu juga diperkuat dengan hasil penelitian lain yang memaparkan bahwa anemia pada kehamilan trimester III mempunyai risiko 16 kali lebih besar untuk melahirkan BBLR. ${ }^{24}$

Setelah dilakukan uji regresi, diketahui bahwa faktor determinan terjadinya berat badan lahir bayi di Puskesmas Suruh adalah tingkat kecukupan protein, asupan $\mathrm{Fe}$ dan kadar hemoglobin. Secara statistik, tingkat kecukupan energi memiliki $r=0,568$ lebih besar dibanding tingkat kecukupan protein $(\mathrm{r}=0,541)$ namun keduanya berperan sama dalam kehamilan.

\section{SIMPULAN}

Ada hubungan antara tingkat kecukupan energi, tingkat kecukupan protein, asupan Fe/hari, asupan folat/hari, lingkar lengan atas dan kadar hemoglobin dengan berat badan lahir bayi. Secara multivariat, tingkat kecukupan protein dan asupan $\mathrm{Fe} /$ hari ibu hamil trimester III merupakan faktor 
determinan berat badan lahir bayi di wilayah kerja Puskesmas Suruh.

\section{SARAN}

Bagi tim pelaksana gizi di Puskesmas Suruh untuk memberikan penyuluhan kepada ibu hamil agar meningkatkan asupan gizi ibu hamil terutama protein dan zat besi, sehingga tidak terjadi berat badan lahir rendah. Penyuluhan dapat dilakukan pada pemeriksaan antenatal care atau kelas ibu hamil.

\section{DAFTAR PUSTAKA}

1. Pantiawati I. Bayi dengan berat badan lahir rendah. Yogyakarta: Nuha Medika; 2010. hal.6-20

2. UNICEF. A world fit for children. USA: United Nation General Assembly; 2002.

3. Badan Penelitian dan Pengembangan Kesehatan Departemen Kesehatan RI. Laporan hasil riset kesehatan dasar 2010. Jakarta; 2010. hal iv, $140,170,187$.

4. Arisman MB. Gizi dalam daur kehidupan. Edisi 2. Jakarta: EGC; 2009. hal 4-20.

5. Mutalazimah. Hubungan lingkar lengan atas (LLA) dan kadar hemoglobin $(\mathrm{Hb})$ ibu hamil dengan berat bayi lahir di RSUD Dr. Moewardi Surakarta. Jurnal Penelitian Sains \& Teknologi 2005; 6(2): hal 114126.

6. Mitchell MK. Nutrition across the life span. $2^{\text {nd }}$ ed. USA: Elsevier; 2003.p.145-167.

7. Williamson CS. Nutrition in pregnancy. British Nutrition Foundation Nutrition Bulletin; 2006: 31, p.28-59.

8. Charles DHM, Ness AR, Campbell D, Smith GD, Whitley E, Hall MH. Folic acid supplements in pregnancy and birth outcome: re-analysis of a large randomised controlled trial and update of Cochrane review. Pediatric and Perinatal Epidemiology; 2005: 19, p.112-124.

9. Arkkola T. Diet during pregnancy:dietary pattern and weight gain rate among finnish pregnant women. Universitasis Ouluensis : D medika 1037; 2009.

10. Institute of Medicine. Weight gain during pregnancy: reexamining the guidelines. Washington DC: National Academy Press; 2009.

11. Almatsier S, Soetardjo S, Soekatri M. Gizi seimbang dalam daur kehidupan. Jakarta: Gramedia pustaka utama; 2011. hal 189.

12. Bloom L, Escuro A. Adolescent pregnancy : where do we start. In : Keefe CJL, Couch SC. Philipson EH. Handbook of Nutrition and Pregnancy. USA: Humana Press; 2008. p. 101-103.

13. Suhardjo. Berbagai cara pendidikan gizi. Jakarta: Bumi Aksara; 2003.

14. Roberts BSW. Maternal Nutrition: The biginning of life and the physiology of pregnancy. In: Roberts BSW, Williams SR. Nutrition throught the life cycle. $4^{\text {th }}$ ed. USA: The McGraw-Hill Companies; 2000. p. 57-59. 87-88.

15. Khoushabi F, Saraswathi G. Assosiation between maternal nutrition status and birth weight of neonates in selected hospitals in mysore city india. Pakistan Journal of Nutrition; 2010: 9 (12).p. $1124-$ 1130.

16. Nelms M, Sucher KP, Lacey K, Roth SL. Nutrition therapy and pathophysiology. $2^{\text {nd }}$ edition. USA: Wadsworth; 2007. p. 38-50.

17. Rolfes SR, Pinna K, Whitney E. Understanding normal and clinical nutrition. Eight edition. USA: Wadsword; 2009. p. 338-342, 442-451, 477-500.

18. Hazhir MS, Abdy S, Roshani D, Shahghaibi S, Jamshidi R, Gharibi F. Nutritional status and some related factors among pregnant women in Iran. Life Science Journal 2013;10(7s).

19. Kolte D, Sharma R, Vali S. Correlates between micronutrient intake of pregnant women and birth weight of infant from Central India. The Internet Journal of Nutrition and Wellnees. 2009. Volume 8(2). DOI: $10.5580 / 1979$.

20. Muthayya S. Maternal nutrition and low birth weight-what is really important?. Indian J Med Res 130; 2009: p. 600-608.

21. Ma'rifah U. Hubungan status gizi ibu hamil berdasarkan ukuran lingkar lengan atas dengan berat badan bayi lahir di BPS $\mathrm{Hj}$. Tinik susilowati sidoarjo. UM Surabaya; 2011.

22. Qobadiyah TP, Musta'in, Maryanti. The influence of size upper arm circumference (LLA) third trimester pregnant women on the birth weight babies In BPS Siti Sujalmi Jatinom Klaten. Jurnal Ilmu Kesehatan; 2012: Vol. IV (2).

23. Amiruddin. Asupan gizi pada ibu hamil. 2007. [diakses: 12 februari 2013] http:www.scribd.com/doc/47810533/makalahanemia-bumil.

24. Haryanta W. Hubungan antara kadar hemoglobin rendah pada ibu hamil trimester tiga dengan berat bayi lahir rendah di bangsal Gladiol BPK rumah sakit umum Kabupaten Magelang tahun 2008. Unimus; 2008. 